\title{
IMPLEMENTATION OF EDUCATION MANAGEMENT STANDARD IN THE GUIDANCE OF PRIVATE ISLAMIC HIGH SCHOOL
}

\author{
Herson Anwar \\ State Islamic Institute (IAIN) Sultan Amai Gorontalo \\ Jl. Sultan Ama, Kayumerah, Limboto, Gorontalo, Indonesia, 96181 \\ Email: herson.anwar@gmail.com
}

Received: 03, 2018. Accepted: 06, 2018. Published: 06, 2018.

\begin{abstract}
This study aimed to review the implementation of education management standard for the development of private Islamic high school. This is the case study in Gorontalo City (one of big city in Indonesia). This study investigates the process of program enforcement, such as the management of curriculum section and learning activities, students, teachers and staffs, facilities, monetary sections, culture and school environment, as well as public relation and partnership. Data were collected by observation, interview, and the documentation. The result showed that the standard implementation of education management under the guidance of private Islamic high school has been conducted even there are some management components, which are not yet well conducted as the standard. The challenges are the low interest of parents to enroll their children at madrasah, unrepresentative service, inefficient financial planning, government and foundation policy, free education program, public relation program concern more on an internal program, and also the lack of parents' knowledge about Islamic high school. The potencies of Islamic high school such as religion curriculum, extracurricular program, and complete facilities should be optimized.
\end{abstract}

Keywords: Education Management Standard, Guidance, Private Islamic High School.

\begin{abstract}
ABSTRAK
Penelitian ini bertujuan mengkaji implementasi standar pengelolaan pendidikan dalam pembinaan Madrasah Aliyah Swasta di Kota Gorontalo yang difokuskan pada proses pelaksanaan program yaitu: pengelolaan bidang kurikulum dan kegiatan pembelajaran, peserta didik, pendidik dan tenaga kependidikan, sarana dan prasarana, bidang keuangan dan pembiayaan, budaya dan lingkungan madrasah, bumas dan kemitraan. Selain itu untuk. menganalisis tantangan yang dihadapi sehingga dapat memaksimalisasinya. Metode penelitian yang digunakan adalah penelitian kualitatif dengan pendekatan studi dan metodologis. Data dikumpulkan melalui observasi, wawancara, dokumentasi yang dianalisis secara deskriptif. Hasil penelitian menunjukkan babwa implementasi standar pengelolaan pendidikan dalam pembinaan Madrasah Aliyah Swasta sudah terlaksana meskipun ada beberapa komponen pengelolaan yang belum terlaksana sesuai dengan standar pengelolaan pendidikan. Tantangannya adalah rendahnya minat orang tua dan masyarakat untuk menyekolabkean anaknya di madrasah, layanan yang belum representatif, perencanaan keuangan yang kurang matang, kebijakan pemerintab dan yayasan, adanya program pendidikan gratis, program kerja bumas lebih fokus terbadap program internal, pengetahuan orang tua tentang madrasah kurang. Maksimalisasi keunggulan yang sudah dimiliki madrasah, seperti kurikulum agama, ekstra kurikuler dan memanfaatkan kelengkapan sarana dan prasarana yang dimiliki. Mengingat masyarakat belum mengetabui dengan pasti seperti apa sistem pendidikan, kualitas dan prospek dari madrasah, maka maksismalisasi pencitraan terhadap Madrasah Alivab Swasta perlu untuk terus dilakukan dan ditingkatkan.
\end{abstract}

Kata Kunci: Standar Manajemen Pendidikan, Panduan, Sekolah Tinggi Islam Swasta. 


\section{INTRODUCTION}

Recently, there are still a lot of problem in education field. The main problem is the cost of teaching process that must be covered either by school or students. Thus, alternative ways for utilizing minimum resources are to get the objectives for school (Ngozi Amanchukwu \& Ololube, 2015). The records play a significant role in gaining effective school management. If the records are not well managed, the school management function will be in problem (Gama, 2010). Good record transcends short and long-term benefits and affects the overall achievement of educational objectives (Kuh, Cruce, Shoup, Kinzie, \& Gonyea, 2008). Regarding the management of Madrasah, the government has initiated the education autonomy in the developing of the quality of madrasah (Fullan \& Watson, 2000; Parker \& Raihani, 2011).

The development of Madrasah as a managerial subsystem is very depending upon the management as a whole of Madrasah subsystem, whether independently or as a whole system (Lubis, Yunus, Embi, Sulaiman, \& Mahamod, 2010; Sabri, 2014). The management of Madrasah is an affective review of Madrasah from the perspective of arrangement made by the principal of Madrasah to the field work, such as students, staffs, curriculum, facilities, finances, and partnerships between Madrasah and the society (Machfudi, 2017).

Formally, Madrasah in Indonesia divided into two types: State Madrasah and Private Madrasah. However, in the beginning, all Madrasah are under the ministry of religion as a private school that is established and initiated by local Islamic society. The establishment of State Madrasah has been formed recently on the other sides from the government as the way to help and guide a private madrasah (Hashim, Rufai, \& Nor, 2011).

The fact shows that the tardiness of private madrasah is as the effect of the limited fund, facilities to support the guiding, and the weakness of management pattern in a guidance system, with the traditional management (Sofo, Fitzgerald, \& Jawas, 2012). In addition to that fact, there is no conducive governance where it creates not transparent and not accountable management, including the partnership intensity between related components, those are boards of foundation and Madrasah, and the parents seem to give lack contributions to the development of Private Madrasab (Triwiyanto \& Juharyanto, 2017). Therefore, the research investigated about the guidance of Madrasah, especially to the Private Madrasah Aliyah.

Private Madrasah Aliyah as a part of national education organizers is in charged to be able to carry out the education as the prevailing management standard of education, which is applied nationally (Regulations Number 13 Year 2015 article 1 verse 10) (Muttaqin, 2012). On the contrary, there is a minimum standard of education that should be fulfilled by madrasah in doing the management of education based on national ministry regulations Number 19 Year 2007 about the educational management standard which is reinforced by the regulations of government Number 13 Year 2015 (see https://think-asia.org/ bitstream/ handle /11540/4385/ACDP-020-Evaluation-of-International-Standard-Schools-in-Indonesia _LM_RM.pdf?sequence=1).

Since the research investigating about Madrasah Management especially in Private Islamic School in Indonesia is still rare to find, this study is trying to evaluate the implementation of education management standard for the development of private Islamic high school. As a model, we selected one of private Islamic high school in Gorontalo City. Different from other reports, this study was focused on the process of program enforcement. Specifically, the study evaluated management of curriculum section and learning activities, students, teachers and staffs, facilities, monetary sections, culture and school environment, as well as public relation and partnership. Since many people still do not understand clearly about the Islamic education system (based on some of previous studies), quality, and prospect of Islamic high school, this study may open the ideas about the importance of Islamic high school in society. 


\section{METHOD}

The research methodology used in this research was a qualitative research. The research was conducted in the Private Madrasah Aliyah at Gorontalo City (Islamic Senior High School in Indonesia). Data were collected by observation, interview, and documentation. In this study, data analysis was done by several stages, namely data collection, data reduction, display data, conclusion and verification of data. In addition, this study also implement editing, categorization/coding, and meaning making. In the data editing process, the data were translated and converted. The data that could not be read then it was translated to be readable and understandable. In the coding stage, data categorization was applied in accordance with the focus of research problems. To gain meaning, this study interpreted the analyzed data according to the focus on the problem to be given meaning. Conceptualization of scientific statement was also added as the conclusion from the research.

\section{RESULTS AND DISCUSSION}

The management of education by educational institution, especially Madrasab is reffering to National Education Ministry Number 19 Year 2007 about an education management standard. In this regulation, technically it rules related items, including the program planning, program implementation, evaluation and guidance, leadership of Madrasah, management information system and special assesment. To understand the implementation of education management standard for the guidance of Private Madrasah Aliyah at Gorontalo City, it is limited to the process of program implementations, those are: (a) the management of curriculum and learning activity, (b) the management of students, (c) the management of teachers and education staffs, (d) the management of facilities, (e) the management of finance and financing, (f) the management of culture and school/madrasah environment, $(\mathrm{g})$ the management of partnerships.

If the whole potencies in the Private Madrasah Aliyah at Gorontalo City are empowered optimally, it can increase the quality of education in Madrasah Aliyah, even though there are many challenges faced. With all advantages possessed by Madrasah, it can be a basis for the fulfillment of the targets in accordance with its purpose, and the presence of Madrasah as an Islamic Education Institution is based on the independency and partnership with various elements of society, with the willingness to have active roles in building and guiding the Madrasah.

As an effort to make Private Madrasah Aliyah becomes interesting for society, the education management should be improved. The improvements cover the program planning, the implementation, supervision and evaluation to the academic environments, facilities, curriculum, studentships, human resources, funding, as well as learning and partnerships. This can involve all educational stakeholders in Madrasah. In turns, this creates sense of belonging from them and society. Through the management of education in that Madrasah, it is expected to realize the effective madrasah guidance, which is a strong profile, independent and conducive for conditions in society to develop critical attitude, creativity, and high motivation.

\section{The Management of Curriculum and Learning Activities}

Teacher is one of important factor in the management of curriculum and learning activities. If the teacher doesn't understand the management, some problems might appear such as do not understand the development of new curriculum, get difficulties in arranging syllabus, and promote not various teaching methods. Thus, the guidance reconstruction is necessary to be conducted, in which it will give a chance to teacher for continuing education to the higher level and relevant with their skills.

Guidance reconstruction is necessary to be conducted in maximizing the management of curriculum and learning activities, such as: 1) curriculum used is flexible, it is adjusted to the 
condition and the needs of students and environment; 2) the reduction of subject in school or the reduction of subject material, because 19 subjects (47-55 hours) per week are a very big burden, if it is compared with general senior high school, which only have 15 subjects (39 hours per week); 3) the major material at least 5-7 hours, and the others will be decreased, and it will be added to the major material; 4) the majoring can be started since the first year (Class X), so the deepening and the maturing of the major knowledge can be more optimal. The essence of the guidance of curriculum management and learning activities is demanding Madrasab to have independency, creativity, innovation, and initiative in managing curriculum.

Madrasab should have enough human resources and institutions to be able to manage curriculum (Alam, Ismail, \& Mishra, 2010). Hence, Madrasah should be able to do the developments and managements of curriculum, creating a curriculum development team, do a workshop in developing curriculum, and arranging curriculum with involve various related components, mainly for the teacher.

The development of curriculum that should be noticed generally is the management of Madrasah curriculum, Madrasah Curriculum has uniqueness with its Islamic education, but it should be thought about how to level the curriculum which becomes guidance for all schools within the group of general school. Madrasah Aliyah is included in the group of senior high school so the content of general knowledge should contain skills that must be mastered by its graduates.

\section{The Management of Students}

The findings from the research related to the management of students are obtained from the implementation of new students recruitment, the counselling service, extracurricular, the main achievement guidance which is conducted as the appropriated indicator, even though on the guidance, and counselling aspect. It is necessary to be formulated the planning of the program which covers activities at the learning time or outside the learning time. On the contrary, the factor becomes obstacles, such as 1) the lack of learning facilities and there is nogood planning from Madrasah in deciding the numbers of students who will be accepted, it makes there is no certain regulation in accepting new students, and it causes the number of accepted students is not balanced by the number of students who should be accepted for the class, 2) the supervision over the students cannot be continuously well implemented in the controlling or directing in the activities related to students, 3) the lack of readiness from the organizer of education at Madrasab in managing students.

Many private Madrasah are not able to survive because they are out of the number of the students. Even, the chief of foundation ever said that it was more difficult to get new students than to get the new teachers. Further, he said that for getting the new teachers it was only by opening the job vacancy announcement and then applicants will come easily. In contrast, to find new student is very difficult, and it is not enough by spreading brochures and putting announcements in the street to gain the students. This factor shows that the education activity in this competition era, student is the main component which should be managed and be appreciated their dignity, and it is not different with buyer/consumer just like in business (Kehinde, 2009).

The guidance reconstructions, which is needed to do in maximizing the management of students, are 1) new student's acceptance, Madrasab is permitted to accept and recruit students as many as possible, but it should be adjusted with the facilities and with the available classroom, if the quantity of students is huge but the quality is not good enough even become an ineffectiveness on the teaching-learning process, so it should be noticed by looking at the number of classes and available facilities; 2) the students' requirement committee of Madrasah should decide minimum score standard or the average of passing grade scores on the selection of new students, and that way can be used to produce new students who really have good 
competences and have good quality in guiding or managing at studentship fields; 3 ) it is necessary to have a coordination through the studentship activities, the using of tools, the setting of times, giving and accepting suggestions, directing and guiding by principal and teachers in the form of dividing and giving assignment clearly, explaining the way to do assignments properly.

The effective and well managed Madrasah can rule the principles in managing students (Rose, Greeley, \& Fragile States Group OECD. Development Assistance Committee, 2006) to increase the understanding and the acceptance for philosophy, values and missions in giving planning for whole activities of Madrasah, noticing on the achievement of the most important targets and the goals and also to decide the priority that should be reached; 2) effective and flexible leadership from the principal of Madrasab in influencing the Madrasah policy and the implementation of the program with clear planning and implementation; 3) deciding the clearly high standard for behavior and performance, there is high teamwork among teacher, principal of Madrasah, students and society in advancing the development of Madrasah.

Students at Madrasah Aliyah level have specialty where the students come from the group of middle to low class society and the issue about the skill which is under the general school. However, it does not mean that the process of studentship services becomes different; specifically it should be the same with other schools.

\section{The Management of Teacher and Education Staff}

The management of teacher and education staff ideally should contain the implementation of competency improvement and the qualification of teacher and education staff through MGMP (Musyawarah Guru Mata Pelajaran/Teachers' Forum), joining the course/training, seminar, workshop, which is held at the Madrasah level, city or province, whether for teacher or education staff as appropriated for madrasah program.

The finding from this research related to the management of teacher and education staff is the lack of teacher who is appropriate with their skill qualification. Besides, there is the lack of the number of teacher with the needs of subject which is taught. This finding has also become the national problem which is common to be faced by every education institution.

The problem of education which recently has influenced national education is the source of teacher who is not professional yet (Little, 1993). The factor which inhibits the development of Madrasah along the time is the limited numbers of teacher, unclear status of teachers and the inadequacy of teacher qualifications.

The reconstruction of the guidance which is necessary to be done in maximizing the management of teacher and education staff as appropriated as the standard of education management that it is needed the guidance through MGMP forum and the improvement of quality through further study. In case of this guidance, it is necessary to adjust the perspective and action to take between education ministry and religion ministry, to all teachers who teach at Madrasah Aliyah and teachers who teach at general Senior Highs School, so they can work together for increasing the quality of teacher, and it will lead to the increasing of graduate's quality. Besides that, the existence of laboratory staff, librarian, office staff and the others should fulfill the adequacy and quality standard.

\section{The Management of Facilities}

The findings from the research related to the management of education facilities, such as: 1) the lack of available funding, 2) the lack of treatment and maintenance of facilities because the limited workers to manage it, 3 ) the books for the library are not complete and not enough to support the learning process as the needs of students; 4) the supporting facilities in fulfilling management education standard are not fulfilled optimally such as: suitable library, counseling and guiding rooms, student organization rooms and other supporting facilities. 
The weak point of education is caused by the bad education equality which is less supported by available facilities (Kezar, 2004). Hence, the reconstruction of guidance needs to be conducted in maximizing the management of facilities, they are: 1) guidance effort implemented in the class is emphasized in the procurement sides because it needs many supporting facilities and the government cannot directly give the fund to the foundation. Furthermore, the allocation from the fund from government is optimally directed toward the improvement of needed facilities; 2) it is needed to intensify the supervision and direction in every activity of education facility's management so in its activity is running well and effective for reaching the goals that have been targeted before, and 3) teacher can be more competent in using education facilities to support the learning activities in the class and the partnership with Madrasab facility's section to make the management of facilities in Madrasab run well.

The management of Private Madrasah Aliyah facilities should fulfill the minimum service standard requirements. Besides, it can be seen from the fulfillment of quantity sides. It also shows the quality sides of education facilities.

\section{The Management of Finance and Financing}

The finding of the researches in the management of finance and financing are influenced by main source funding depends on the government policy, where Madrasab does not have independency in managing its finance and financing because all of them depend on government policy.

This finding is in line with other references that in the education funding, there is something likes "pulled out policy" between the education enhancement and education equality (Ball, 2012). In this case, the government will need deepest thought to find the way. This will be done in order to solve the problems in an effort in enhancing the quality of education through the funding. This is because the enhancement of quality education should go through the enhancement of learning process to the class, and the learning process to the class will be highly qualified if there is an organized big funding. The calculation of the funding of educational cost should be implemented as accurate as possible with the component of education activity and unit cost, and if it has been done so by analyzing the using of every education funding becomes an avoidable step to do.

In enhancing the quality of education, it is important to notice the big budget of education, which is allocated (revenue), the justice aspect in the budgeting allocation, efficiency aspect in the utilizing of budget, and the decentralization of education management (Jongbloed, Maassen, \& Neave, 1999). From this opinion, it needs to be underlined that on the justice aspect in the budgeting allocation. If it is related to the finding from the data which is obtained by the writer so it will show that the allocation of budget for the guidance and the development of Madrasah facilities, which is not balanced yet if it is compared to the budget given to schools under the national education ministry. As the result, the facilities of education in Madrasah are generally not as good as those on the general school. However, it should be admitted that the education budgeting in Indonesia is still low.

In the enhancement of Indonesian people quality, the government is not one system, which is free with private sector and society. The relationship between government, society, and private sector is cannot be separated from its role in increasing the equality of education quality. Generally, education is approved as an infestation of human resources. If we put the position of education in terms of educating the nations in the context of good society, it needs the big investment bravery to strengthen the national education system (Huxley, 2017).

The reconstruction of the guidance which needs to be done in maximizing the management of finance and financing sector is very important to have the attention from the government about the education budgeting which is given fairly and proportionally. To make Madrasah, people must have its independent funding budget and have independency in 
managing the finance and financing. This also does not depend on education policy. E Madrasah needs to make the planning of financial source from external sector of Madrasab itself. One of the ways is by the making of a partnership proposal in order to enhance the funding donator relationship, initiating the reunion of alumni in order to collect financial supports, and others. The most important thing in realizing the budget is how the way to make an effective and efficient financial, and it can be allocated properly as the priority scale, and also it can support every process of education activities in every Madrasah.

The effort of guidance above is in line with what Harbangan Siagian said that to enhance the quality of private schools because of the limited budget that they have is by giving helps from the government, such as: 1) the placing of civil servant teacher to help, 2) special aids in the establishment of school building and all supported facilities inside it, 3) regular money for daily needs of school, this aid is possibly in the form of donations, helps, or subsidies. The donation can be given incidentally to cover at least the daily needs, while the helps can be given based upon the numbers of student, and also the subsidies can be given to cover all daily outcomes of school (Bekkers \& Wiepking, 2010).

Similar with what described in other references that the regional autonomy policy let the problems arose (Bardhan, 2002). Then, they are handled by regional government and school. Thus, the funding problems also become the obligation to the school to manage them independently. In this case, the principal of Madrasah has financial responsibility. Thus, it needs to be conducted some efforts to increase the financial condition of the school. Becoming a professional principal should have the ability in managing school/Madrasah.

The management of financing sector, activities which make the cost of study of the Madrasah level become higher can be well identified, when the uniqueness in the organizing of education at Madrasab level which possibly cause the differences in the financing at the same level.

\section{The Management of Culture and Environment}

Related to the management of culture and environment Madrasab has various cultures like physical culture and behavior culture. Physical culture can be seen from the physical display from five Madrasah Aliyah, which become the object to the research. Then, behavior culture can be seen from religious culture, discipline culture and the obedience of school regulations, achievement and competition culture, reading culture and cleanness culture. The physical appearances of school culture element can be seen from the equipment of facilities, school building, which is completed by fence, motto or writings in the strategic places.

The challenges faced by the management of culture and environment sector, such as: 1) the lack of awareness from people inside Madrasab in keeping the cleaning and maintaining available facilities, 2) the establishing of regulation and discipline, which are not optimal yet and sometimes there is not discipline teacher or staff, so it causes the learning process not goes well and becomes not a good model in the front of students, 3) the background of student's family who did not optimally direct their children for always being discipline into their lives.

The reconstructions of guidance which needs to be done by Madrasab for maximizing the management of culture field and the environment of Madrasah, such as: 1) Madrasab/school should make a change by accustoming reading culture and also the maintenance management for the existence of all activities in the Madrasah/school; 2) every Madrasah should increase the role of all people inside Madrasah with giving attention to the people inside Madrasab to use optimally the available facilities from the learning equipment or from the facilities to support the culture in Madrasah.

The management of culture and the environment of Private Madrasah Aliyah should increase the role of all elements in Madrasab by appealing to all elements in Madrasah to utilize optimally the facilities, whether from the learning equipment or facilities to support the culture in Madrasah. 


\section{The Management of Public Relationship and Partnership}

The finding from the research related to the management of Public Relationship and Partnership such as the guarantee of education quality, healthy field, character building, the management of facilities, and also to increase the relationship among surrounding societies through the various social activities or others, so the implementation on the management aspect of public relation and partnership activity with the decided indicator. Furthermore, on the planning program aspect in the development and the enhancement of school quality which is unwell implemented, so the implementation of other aspects, which generally support the development and the enhancement with the decided indicator.

The challenges which are faced in the management of public relation and partnership, they are 1) the work program of public relation should more focus on the programs of guidance giving to internal society, whereas external society is not totally noticed; 2) public relation organization is not massive because the organization structure of public relation is only posited by a vice principal of Madrasah and does not have other staffs; 3) the knowledge of a parent about Madrasab is lacked from the condition to the building and also its learning process; 4) the limited number of teacher and office staff and also financial resource which are had by every Madrasah and makes the limited activities can be held by public relation.

The relation of society is increasing good relationship between whole components at an institution in order to give understanding, create the motivation and participation. It has a purpose to increase and develop the understanding and the good willingness and also get advantageous public opinion or create good teamwork based upon the god relationship with public. The society relationship with education is very correlative, even it is just like chicken with egg. Society is advanced because of education, and the advanced education can be found in the advanced society (Hega \& Hokenmaier, 2002). Then, structurally Public Relation is an important activity in all works so the school or an educational institution has an official medium to interact with society and also show the recent and previous activities.

The fieldwork of Public Relation in an organization or another institution consisted of some activities as follows: 1) guiding the relation to inside (internal public). Internal public is a public that becomes the part of unit, institution, company, or organization itself. A Public Relation Manager should be able to identify or recognize the things which create negative description in the society, before that policy is ruled, 2) guiding relationship to outside (external public). External public is the general public (society). It initiates the development of attitude and the positive public picture of the represented institution (Brunsson \& Sahlin-Andersson, 2000).

The reconstruction of guidance which is needed to be conducted in maximizing the management of public relation partnership, as follows: 1) enhancing the advantage which is possessed by Madrasah, like religious education curriculum, extracurricular activities, and utilize the completeness of facilities, 2) doing collaboration with all elements of society, like work together with influenced society figure, the government, press, radio station, and the others, to introduce Madrasah, 3) utilizing the extracurricular activities such as: marching band, scouts, national day celebration, Islamic day celebration or other events to more popular Madrasah to society; 4) enhancing the advantage which is already had by Madrasah, like religion-based curriculum, extracurricular and well utilize the completeness of facilities, 5) identifying and analyzing the needs and the willingness of the society.

Various challenges which are faced in the standard implementation process in the management of education under the guidance of Private Madrasah Aliyah at Gorontalo City found in the background of this research is describing that in its implementation is not easy, but it needs serious and consistent effort to reach the goals. The management of Madrasab is appropriated with the management standard to this case as it should maximize the education 
management standard in every Madrasah. This is to make all challenges to become a power and finally to become chance to survive and compete with State School/Madrasah.

The chance of Private Madrasah Aliyah at Gorontalo City as a school with Islamic characteristic has more religious value than common general school. This plus value supposed to give advantage and benefit to the prestige and competing level of Madrasab in increasing the society's interest, and if Private Madrasah Aliyah at Gorontalo City can promote it well especially in the decreasing of religious values among societies, so the chance to have people interest about Madrasah Aliyah at Gorontalo City will be bigger, because only madrasah which has religious curriculum content and has the more religious program.

Private Madrasah Aliyah at Gorontalo City actually has more potential, not only in religion knowledge but also in technologies and natural sciences. The selection for new students takes form an interview (oral test) about the skill in Al Qur'an recital, personality test also added as one of the interest tests. This personality test was also to motivate and it is a good strategy to get a candidate of new students who is not only good in general knowledge but also can recite $\mathrm{Al}$ Qur'an and having good manner and personality. This is because Madrasab is a symbol of Islamic education. From the selection process of new students above, it can be known that Private Madrasah Aliyah at Gorontalo City is not only expecting big numbers of test participants but also expecting candidates of students who have good quality. Unfortunately, the good intention from Private Madrasah Aliyah at Gorontalo City does not get positive supports from society. This is proved after the test that the number of registrants is decreasing from year to year. The candidates of student who cannot recite $\mathrm{Al}$ Qur'an then become scared or unconfident to register at Private Madrasah Aliyah at Gorontalo City.

Here the importance of public relation that it should be able to give an explanation to be public about all advantages which become the credit point from Private Madrasah Aliyah at Gorontalo City, so the expectation to make Private Madrasah Aliyah at Gorontalo City as a main choice of society can be realized. Hence, Private Madrasah Aliyah at Gorontalo City should increase the quality because it can attract the interest from society, besides always doing promotion, whether with direct activity or through the media.

To attract people attention to the society that does not know yet certainly the education system of Madrasah, the quality and the prospect of madrasab must be changed. The society cannot directly believe in the quality of Private Madrasah Aliyah at Gorontalo City. This problem is also added by the more competitive condition from the other general schools which should fix their quality. Thus, it is often to happen that society is doubt about the quality of madrasah or Islamic school.

Thus, the analysis to the weakness, the lack, the chance and the challenge of madrasah should be done by madrasab itself. By patching the weakness, it can measure the ability of further development. The importance of assessment to the ability of organization included madrasah get many theoretical supports. Clearly, without the assessment or the measurement through the organization's ability, it cannot be able to map their skill and ability in order to get further development.

The theoretical explanation shows that the management of madrasab is appropriated with expected management standard which one of the solutions in order to form the independency of madrasah in planning the development of madrasah as the real condition of it. But, it is not easy as that to implement it. There should be a challenge which is faced, and it should be found the solution so the purpose can be reached. The management of madrasah is more macro oriented, which is ruled by government in highest level (centralistic). As a result, much planning at the centre cannot be implemented at school or madrasah (regional level). In other words, the complexity of this educational problem, the condition of madrasah environment and various 
needs of people, it is often not fully and accurately accommodated by the education planner in central level.

\section{CONCLUSION}

Standard management implementation of education for the guidance of Private Madrasah Aliyah at Gorontalo City has been well conducted even though there are some management components, which had not implemented in the education management standard. It needs to formulate the program planning which covers activities as long as the learning and in outside the learning hour. On the management of curriculum and learning activities in the implementation of the counselor role, it is not specific explained. The management of facilities is the only one program which can be conducted and the management of library as one of the learning sources. The management of finance and financing sector which can be implemented is financial management guidance aspect and finance as the official regulation and the responsibility of financial management and financing, which has been done based on available budget. The management of culture and environment which have been implemented is the regulation arrangement, ethical code, ad also ethical awareness program at madrasah. While the management of Public Relation and partnership is more focused on the effort of the guarantee of madrasah education quality through the collaboration in learning guidance, environment aspect, character-building aspect, facility's management aspect through the collaboration with other partners or institutions, which gives product services and involves the society in the activities of madrasah.

The most important essence from the education management standard, mainly in the guidance of Private Madrasah Aliyah at Gorontalo City, is the implementation of education management standard related to the support of infrastructure as the element in enhancing madrasah quality. This appropriates with society needs. This factor will be realized if it is maximized through the innovation in education process and also the approval to the student's successfulness, educational institution which is managed by independency principles, partnerships, participations, open accesses and accountabilities. These are new challenges for Private Madrasah Aliyah, which needs different responses and actions if it is compared with what happened during the past. Furthermore, education management is the most important aspect in deciding whether a Madrasah can optimally implement quality guarantee system or not.

\section{BIBLIOGRAPHY}

Ball, S. (2012). Performativities and fabrications in the education economy: Towards the performative society? (Vol. 27). https://doi.org/10.1007/BF03219719

Bardhan, P. (2002). Decentralization of governance and development. Journal of Economic Perspectives, 16(4), 185-205. https://doi.org/10.1257/089533002320951037

Bekkers, R., \& Wiepking, P. (2010). A literature review of empirical studies of philanthropy: Eight mechanisms that drive charitable giving. Nonprofit and Voluntary Sector Quarterly, 40(5), 924-973. https://doi.org/10.1177/0899764010380927

Brunsson, N., \& Sahlin-Andersson, K. (2000). Constructing organizations: The Example of Public Sector Reform. Organization Studies, 21(4), 721-746. https://doi.org/10.1177/0170840600214003

Fullan, M., \& Watson, N. (2000). School-based management: Reconceptualizing to improve learning outcomes. School Effectiveness and School Improvement, 11(4), 453-473. https://doi.org/10.1076/sesi.11.4.453.3561 
Gama, U. G. (2010). A survey of records management practices in circular primary schools in metropolitan local government area (MLGAs) of Kano State. Samaru Journal of Information Studies, 10(1-2), 23-30. Retrieved from https://www.ajol.info/index.php/ sjis/article/view/75680

Hashim, R., Rufai, S. A., \& Nor, M. R. M. (2011). Traditional Islamic education in Asia and Africa: A comparative study of Malaysia's Pondok, Indonesia's Pesantren and Nigeria's traditional madrasah. World Journal of Islamic History and Civilization, 1(2), 94-107. Retrieved from https://www.researchgate.net/profile/Rosnani_Hashim/publication/268255429_ Traditional_Islamic_Education_in_Asia_and_Africa_A_Comparative_Study_of_Malaysia \%27s_Pondok_Indonesia\%27s_Pesantren_and_Nigeria\%27s_Traditional_Madrasah/link s/56f13ed308aec63f4c9b5145/Traditional-Islamic-Education-in-Asia-and-Africa-A-

Comparative-Study-of-Malaysias-Pondok-Indonesias-Pesantren-and-Nigerias-TraditionalMadrasah.pdf

Hega, G. M., \& Hokenmaier, K. G. (2002). The welfare state and education: a comparison of social and educational policy in advanced industrial societies, 2(1), 29. Retrieved from http://homepages.wmich.edu/ hega/GPS2001MSCRPT.pdf

Huxley, T. H. (2017). Science and Education. Create space independent publishing platform. Retrieved from https://books.google.co.id/books?id=iU09MQAACAAJ

Jongbloed, B., Maassen, P., \& Neave, G. (1999). From the eye of the storm: Higher education's changing institution. https:/ / doi.org/10.1007/978-94-015-9263-5

Kehinde, O. J. (2009). Integrated marketing communications and consumers patronage of nigerian beverage products (Doctoral Dissertation). Covenant University, Ota. Retrieved from http:/ / eprints.covenantuniversity.edu.ng/7836/1/CU03GP0024\%20-

$\% 20$ Kehinde $\% 20$ Oladele $\% 20$ Joseph.pdf

Kezar, A. (2004). Obtaining integrity? reviewing and examining the charter between bigher education and society (Vol. 27). https://doi.org/10.1353/rhe.2004.0013

Kuh, G. D., Cruce, T. M., Shoup, R., Kinzie, J., \& Gonyea, R. M. (2008). Unmasking the effects of student engagement on first-year college grades and persistence. The Journal of Higher Education, 79(5), 540-563. https://doi.org/10.1080/00221546.2008.11772116

Little, J. W. (1993). Teachers' professional development in a climate of educational reform. Educational Evaluation and Policy Analysis, 15(2), 129-151. https://doi.org/10.3102/01623737015002129

Lubis, M. A., Yunus, M. M., Embi, M. A., Sulaiman, S., \& Mahamod, Z. (2010). Systematic steps in teaching and learning Islamic education in the classroom. International Conference on Learner Diversity 2010, 7, 665-670. https://doi.org/10.1016/j.sbspro.2010.10.090

Machfudi, M. I. (2017). The long term impact of an english language teacher training program on teachers' practices in madrasah tsanawiyah in indonesia (Doctoral Dissertation). University of Southern Queensland, Australia. Retrieved from https://eprints.usq.edu.au/ 32869/2/Machfudi_2017.pdf

Muttaqin, A. (2012). Hybrid spirituality and religious efficacy of yogyakarta spiritual centres (Doctoral Dissertation). Western Sydney University, Australia. Retrieved from http://researchdirect.uws.edu.au/islandora/object/uws:12800

Ngozi Amanchukwu, R., \& Ololube, N. P. (2015). Excellent school records behaviour for effective management of educational systems (Vol. 2015). https://doi.org/10.5923/j.hrmr.20150501.02

Parker, L., \& Raihani, R. (2011). Democratizing Indonesia through education? Community participation in Islamic schooling. Educational Management Administration \& Leadership, 39(6), 712-732. https://doi.org/10.1177/1741143211416389 
Rose, P., Greeley, M., \& Fragile States Group OECD. Development Assistance Committee, D. (2006). Education in fragile states: Capturing lessons and identifying good practice. Retrieved from http://s3.amazonaws.com/inee-assets/resources/Rose,_P._Greeley_M_._.pdf

Sabri, A. (2014). Soft skill: Its urgency and development at Islamic higher education. Al-Ta lim Journal; Vol 21, No 3 (2014). Retrieved from http://journal.tarbiyahiainib.ac.id/ index.php/attalim/article/view/109/110

Sofo, F., Fitzgerald, R., \& Jawas, U. (2012). Instructional leadership in Indonesian school reform: overcoming the problems to move forward. School Leadership \& Management, 32(5), 503-522. https://doi.org/10.1080/13632434.2012.723616

Triwiyanto, T., \& Juharyanto, D. E. K. (2017). Community participation deficits in the implementation of school-based management in indonesia. Journal of Education and Practice, 8. Retrieved from http://www.iiste.org/Journals/index.php/JEP/article/view/39724 